beautiful marking on the male proboscis, and because of this omission I was led to hope that a new species had been sent me. However, comparison with the males at the National Museum showed the same marking on the specimens there, and then I found in the description of Simondella curvirostris Laveran ${ }^{1}$ quoted in the monograph of H. D. \& K. the following:

"Près de son origine elle est sombre à la face supérieure et présente, à la face inférieure un petit disque ovale garni d' écailles d'un bleu très vif."

As a matter of fact this little oval group of scales is very brilliant and suggests a sapphire set in the dark proboscis.

As this marking seems to have escaped entirely the notice of both the authorities mentioned it is perhaps worth while to call attention to it.

Army Medical Museum,

Washington, D. C.,

August 14, 1918.

NOTES ON CLOSTEROCERUS CINCTIPENNIS ASHM.," IN NEW JERSEY (HYMENOPTERA)

\author{
By Harry B. Weiss and Alan S. Nicolay \\ New Brunswick, N. J.
}

This species not heretofore recorded from New Jersey has been found by us at the following localities: New Brunswick, Jamesburg, Highbridge, Trenton, Bridgeton and Plainfield, and undoubtedly occurs in many other places in the state. It was described by Ashmead in his paper "Descriptions of Some New North American Chalcididæ" which appeared in Vol. XX, p. 104-1888 of the "Canadian Entomologist" and the habitat given is United States. It is also listed in "The Hymenoptera or Wasp-like Insects of Connecticut" as probably occurring in that state. Neither of the above publications mentions the hosts.

In New Jersey we have found C. cinctipennis to be parasitic upon the eggs and larvæ of Brachys ovata, the eggs of Brachys aerosa and

1 Laveran, C. R., heb. Soc. Biol., liv. 1160. 1902.

2 Identified by A. B. Gahan. 
the larvæ of Phyllonoryter hamadryadella and P. ulmella, all of which are leaf miners. Its habits are therefore similar to those of other members of the genus and allied genera. During the summer of 1918, it appeared to be more common in the Brachys eggs and the larvæ of $P$. ulmella than in the other hosts and only on one occasion was it bred from the larva of Brachys ovata. It constituted a serious pest in the eggs of Brachys sp., which we were trying to rear and was very common in the mines of $P$. ulmella. Adults of $C$. cinctipennis were most plentiful about the first week of July and the pupal stage required about two weeks.

The eggs of Brachys ovata and B. aerosa are too small to support more than one parasitic larva but the mines of $P$. ulmella sometimes contained as many as six pupæ and the size of the mine indicated that only one larva of $P$. ulmella had been present. All of the Brachys egg except the shell is consumed by the larva of $C$. cinctipennis and pupation takes place within the shell. In the case of the larva of $\boldsymbol{P}$. ulmella, everything is consumed except the outer skin and the alimentary canal and pupation takes place anywhere within the mine. The eggs of Brachys which are normally whitish and semitransparent before hatching become black when parasitized. The larvæ and pupæ of $C$. cinctipennis appear to be very similar to those of other members of the family.

Larva: Length $1.35 \mathrm{~mm}$. Width $0.4 \mathrm{~mm}$. Grublike, whitish, subcylindrical, glabrous, rounded anteriorly, pointed posteriorly, anal segment divided, segmentation indistinct, oral cavity on median ventral surface of head, mandibles almost invisible.

Pupa: Length $1.4 \mathrm{~mm}$. Width $0.5 \mathrm{~mm}$. Naked, shining black. The pupa is anchored to the floor of the mine with its posterior end within the cast skin of the larva. Upon holding the leaf up to the light the pupa is seen to be surrounded by from five to eight dark spots arranged more or less symmetrically. These dots are the ends of excrement like supports or beams which run from the roof to the floor of the mine and which undoubtedly prevent the upper and lower leaf surfaces from caving in on the pupa and probably interfering with development. These supports are also present in the parasitized Brachys eggs.

Adult: The following is Ashmead's description of the male:

"Length .04 inch. Head, pleura, sternum, metathorax and abdomen blue; collar, mesothorax and scutellum golden green 
strongly punctate. Head emarginate in front and consequently very thin anteroposteriorly. Antennæ brown-black, hairy. Legs brown, trochanters, tips of tibiæ and tarsi pale or whitish. Wings hyaline, fringed with long hairs, forewings with a brown band extending across the stigmal region and another at the apical margin."

\title{
FIRST ACCOUNT OF A THERMOTROPISM IN ANOPHELES PUNCTIPENNIS, WITH BIONOMIC OBSERVATIONS.
}

\author{
By Werner Marchand.
}

Department of Animal Pathology, Rockefeller Institute for Medical Research, Princeton, N. J.

In the fall of 1915, while taking part in a survey of the breedingplaces of Anopheline mosquitoes in the neighborhood of Princeton, in coöperation with the local Mosquito Extermination Commission, the writer made certain observations on the mosquitoes encountered. This account is restricted to a few facts which appear to be new or serve to clear up some doubtful point in the life history of the mosquitoes. ${ }^{1}$

\section{Bionomics of the Larva.}

In the Princeton region, only two species of Anopheles have been recorded, these being $A$. quadrimaculatus and $A$. punctipennis. The latter species is by far the more common, but, since King's experiments (1916), ${ }^{2}$ it cannot be regarded as entirely harmless. It is doubtful, however, whether this species, which has been found to occur as far north as Boston, Mass. (Th. Smith), ${ }^{3}$ is also in the northern states a regular carrier of malaria.

The larvæ of $A$. punctipennis were kept captive in large numbers and lived best in a flat dish which was left uncovered in order to give free access to the air. In a dish about eight inches in diam-

\footnotetext{
1 The writer wishes, on this occasion, to express his thanks for the kind helpfulness through which his work was facilitated by Professor E. G. Conklin and Professor Ulric Dahlgren of Princeton University. Dr. Conklin also had the kindness to revise the English of the MS.

2 King, W. V. Experiments on the development of malaria parasites in three American species of Anopheles. Jour. Exp. Med., Vol. 23, pp. 703-716, 1916.

Theobald Smith. Notes on the Occurrence of Anopheles punctipennis and Anopheles quadrimaculatus in the Boston suburbs. Jour. Bost. Society of Medical Sciences, Vol. V, pp. 321-324, 1901.
} 

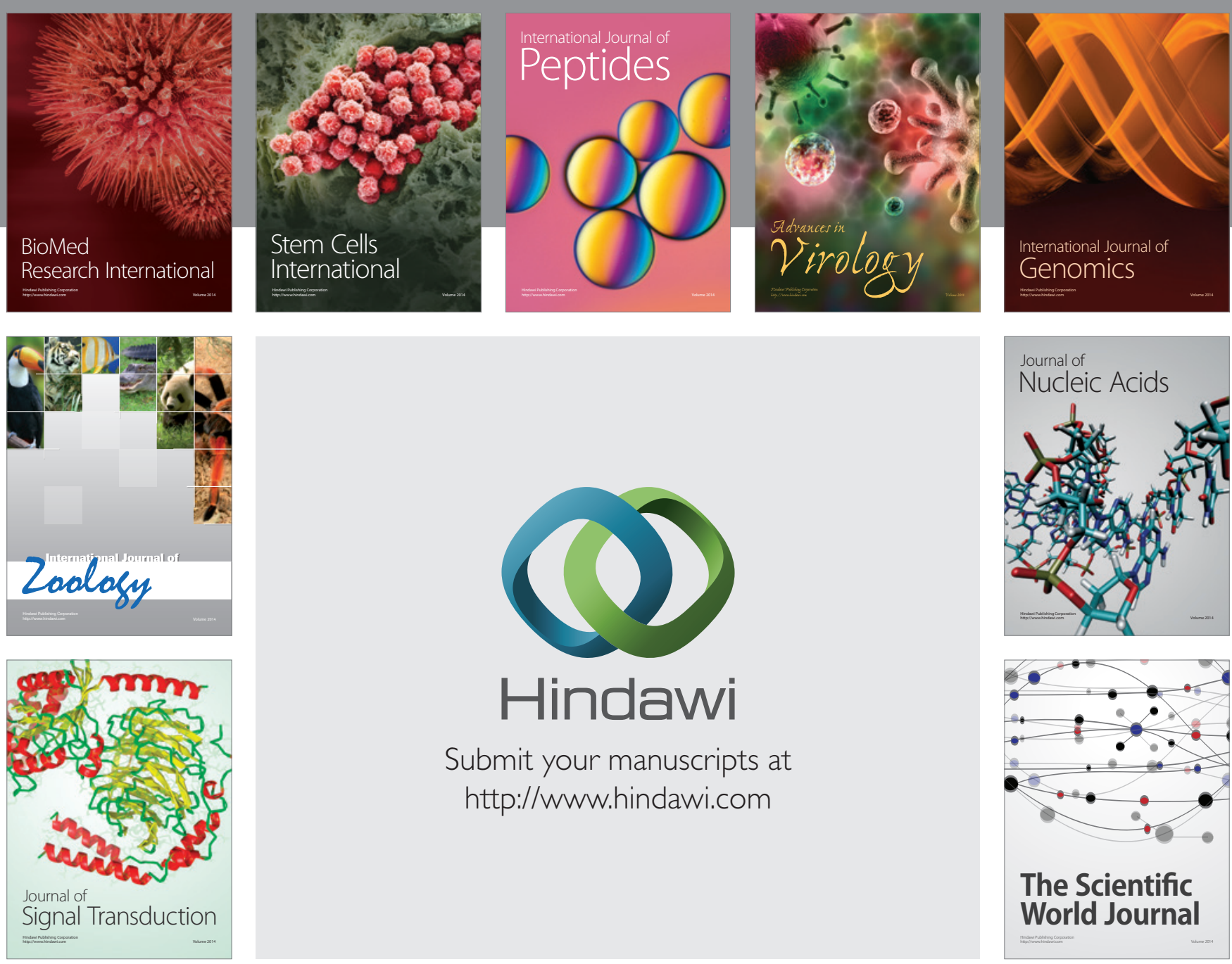

Submit your manuscripts at

http://www.hindawi.com
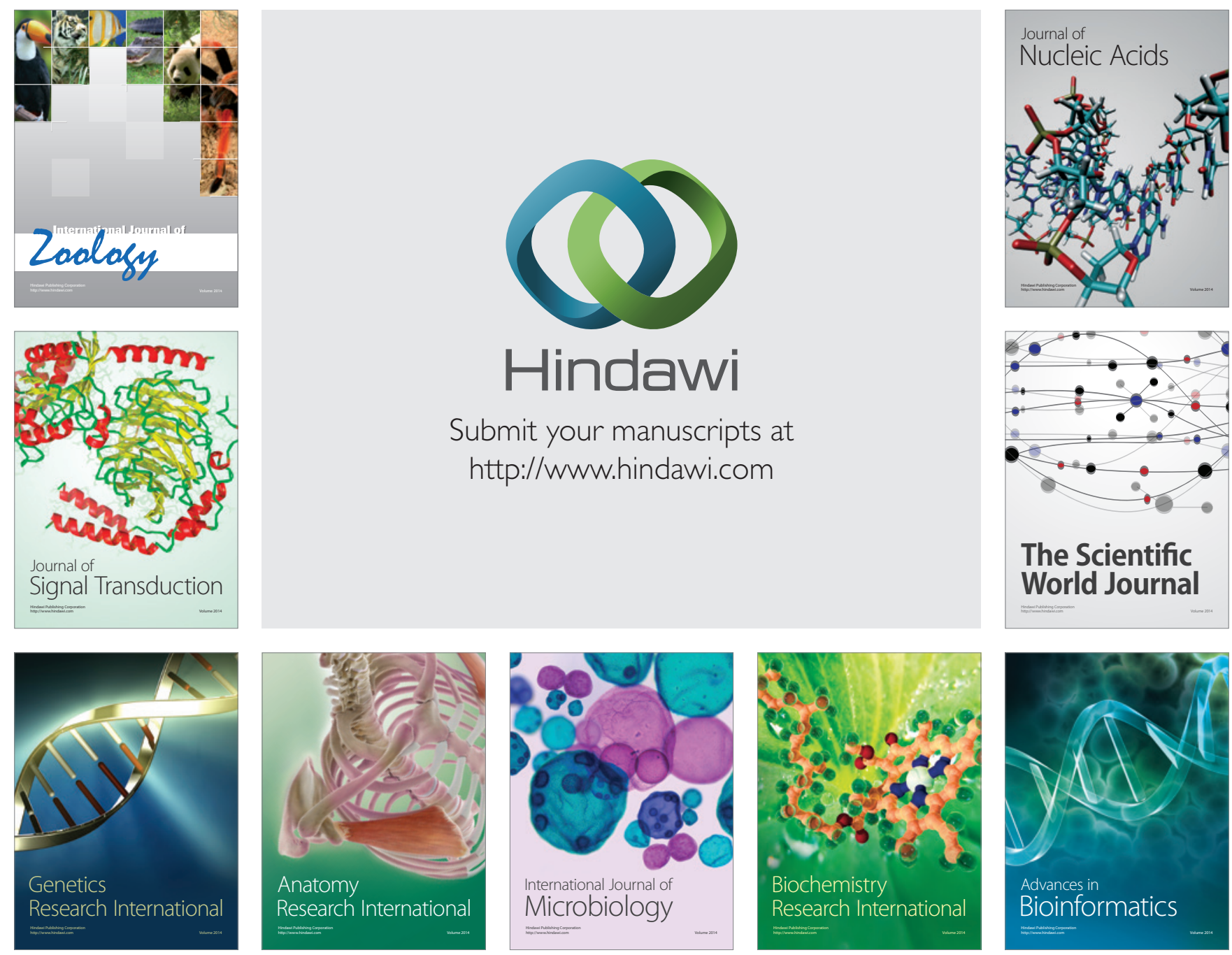

The Scientific World Journal
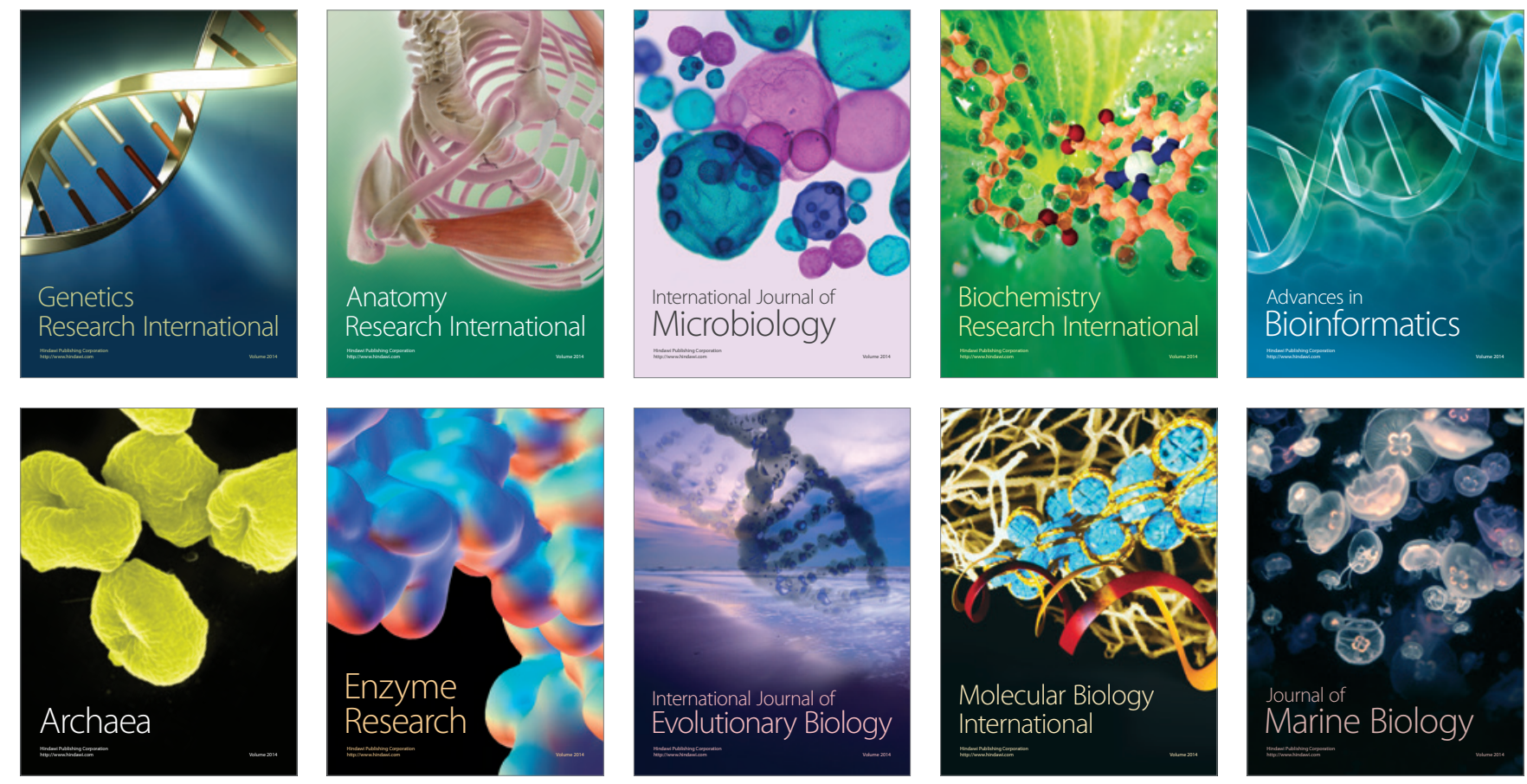